\title{
Isolation of Smenopyrone, a Bis- $\gamma$-Pyrone Polypropionate from the Caribbean Sponge Smenospongia aurea
}

\author{
Germana Esposito ${ }^{1}$, Roberta Teta ${ }^{1}$, Gerardo Della Sala ${ }^{2}{ }^{\mathbb{C}}$, Joseph R. Pawlik ${ }^{3}$, \\ Alfonso Mangoni ${ }^{1}{ }^{(1)}$ and Valeria Costantino ${ }^{1, *}$ (D) \\ 1 The NeaNat Group, Dipartimento di Farmacia, Università degli Studi di Napoli Federico II, via D. \\ Montesano 49, 80131 Napoli, Italy; germana.esposito@unina.it (G.E.); roberta.teta@unina.it (R.T.); \\ alfonso.mangoni@unina.it (A.M.) \\ 2 Laboratory of Pre-clinical and Translational Research, IRCCS-CROB, Referral Cancer Center of Basilicata, \\ 85028 Rionero in Vulture, Italy; gerardo.dellasala@crob.it \\ 3 Department of Biology and Marine Biology, University of North Carolina Wilmington, Center for Marine \\ Science, 5600 Marvin K Moss Lane, Wilmington, NC 28409, USA; pawlikj@uncw.edu \\ * Correspondence: valeria.costantino@unina.it; Tel.: +39-081-678-504
}

Received: 27 July 2018; Accepted: 15 August 2018; Published: 17 August 2018

check for updates

\begin{abstract}
The organic extract of the Caribbean sponge Smenospongia aurea has been shown to contain an array of novel chlorinated secondary metabolites derived from a mixed PKS-NRPS biogenetic route such as the smenamides. In this paper, we report the presence of a biogenetically different compound known as smenopyrone, which is a polypropionate containing two $\gamma$-pyrone rings. The structure of smenopyrone including its relative and absolute stereochemistry was determined by spectroscopic analysis (NMR, MS, ECD) and supported by a comparison with model compounds from research studies. Pyrone polypropionates are unprecedented in marine sponges but are commonly found in marine mollusks where their biosynthesis by symbiotic bacteria has been hypothesized and at least in one case demonstrated. Since pyrones have recently been recognized as bacterial signaling molecules, we speculate that smenopyrone could mediate inter-kingdom chemical communication between $S$. aurea and its symbiotic bacteria.
\end{abstract}

Keywords: Smenospongia aurea; $\gamma$-pyrone; polypropionate; marine sponges; secondary metabolites; signaling molecules

\section{Introduction}

$\gamma$-Pyrones are a large class of biologically active compounds biosynthesized by polyketide synthases, multi-enzyme systems responsible for polyketide assembly through condensation of acyl-CoA units. They are mainly found in marine organisms [1] where they are thought to play a role as allomones or to be biosynthesized for defense purposes [2]. An important class that often contains one or more $\gamma$-pyrone rings are polypropionates, which are polyketides that mostly comprise propionate rather than acetate building blocks. In the marine environment, they are typically found in mollusks [3]. In 2013, Gavagnin et al. [4] reported a comprehensive study of polypropionates (e.g., onchnidionol, Figure 1) from marine pulmonate mollusks belonging to the family of Onchidiidae [5]. This family is known to produce a large array of $\mathrm{C}_{32}$ bis- $\gamma$-pyrones with cytotoxic properties at micromolar concentrations. Earlier in 1996, auripyrones A and B were isolated from the Japanese sea hare Dolabella auricularia [6], which is a species known for being the first source of dolastatin-10 [7]. A synthetic analogue of dolastatin-10 is one of the marketed drugs derived from a marine lead compound, which is the antibody drug-conjugate brentuximab vedotin commercialized under the name of Adcetris ${ }^{\circledR}$. 


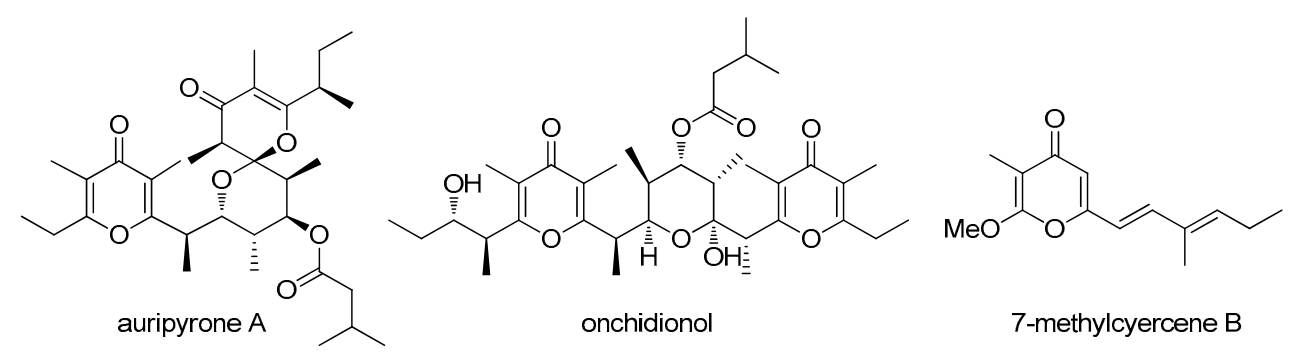

Figure 1. Some $\gamma$-pyrones of marine origin.

Among marine organisms, the sponges' holobiome is one of the richest marine sources of secondary metabolites [8-11] and often provides skeletons with no counterpart in the terrestrial environment. However, no pyrone polypropionates have been isolated so far from a marine sponge. In this paper, we report on the isolation and structure elucidation of smenopyrone (1) (Figure 2), which is a bis- $\gamma$-pyrone compound, from a sample of Smenospongia aurea. The Caribbean sponges of the genus Smenospongia have been previously shown to contain a wide array of chlorinated metabolites deriving from the PKS-NRPS pathway such as smenamides, conulothiazoles, and smenothiazoles [12]. They have been used as guiding structures in our anti-cancer drug discovery programs [13,14].<smiles>CCc1oc([C@@H](C)[C@H](O)[C@H](C)C2=C(C)C(=O)[C@@H](C)[C@H]([C@@H](C)CC)O2)c(C)c(=O)c1C</smiles>

Figure 2. The structure of smenopyrone (1).

\section{Results}

A sample of the sponge Smenospongia aurea was collected along the coast of Little Inagua (Bahamas Islands) in June 2013 at $-15 \mathrm{~m}$ by experts of our group [15]. It was identified onboard of the vessel after the collection and it was immediately frozen and kept frozen until extraction. The sample $(712 \mathrm{~g}$ wet weight) was extracted using our standard procedure involving extraction with $\mathrm{MeOH} / \mathrm{CHCl}_{3}$ mixtures and partitioning between $\mathrm{H}_{2} \mathrm{O}$ and $\mathrm{BuOH}$ [16]. The total organic extract was chromatographed on a column packed with RP-18 silica gel. The fraction eluted with $\mathrm{MeOH} / \mathrm{H}_{2} \mathrm{O}(9: 1)$ was partitioned in a two-phase system composed of $\mathrm{H}_{2} \mathrm{O}(160 \mathrm{~mL}), \mathrm{MeOH}(260 \mathrm{~mL}), \mathrm{CHCl}_{3}(140 \mathrm{~mL})$, and $\mathrm{AcOH}(5 \mathrm{~mL})$. The organic layer was shown to contain known smenothiazoles and smenamides and one unknown compound. This fraction was subjected to repeated reversed-phase HPLC separations, which afford a fraction containing pure smenopyrone (1).

The $[\mathrm{M}+\mathrm{H}]^{+}$ion peak at $m / z 419.2780$ in the high-resolution ESI MS spectrum of $\mathbf{1}$ was indicative of the molecular formula $\mathrm{C}_{25} \mathrm{H}_{38} \mathrm{O}_{5}$, which corresponds to seven un-saturations. No olefinic proton was present in the in the ${ }^{1} \mathrm{H}$ NMR spectrum while the ${ }^{13} \mathrm{C}$ NMR spectrum showed the presence of eight non-protonated $s p^{2}$ carbon atoms ranging from $\delta 109.2$ to 197.9 (Table 1). Combined information from the DEPT spectrum and the molecular formula showed only one $\mathrm{OH}$ group to be present in the molecule. The remaining protons were linked to carbon atoms.

The proton NMR spectrum revealed the presence of nine methyl groups (two triplets, four doublets, and three singlets) out of 25 carbon atoms, which suggests a polypropionate structure. It has been shown that, for methyl rich compounds like 1, the analysis of 2D NMR spectra can conveniently start from the HMBC spectrum [17]. As a result of the presence in $\mathbf{1}$ of nine methyl groups on alternated carbon atoms, the HMBC correlations of methyl protons provided enough information to build the whole carbon skeleton of $\mathbf{1}$ (Figure 3). 
Table 1. NMR Data of smenopyrone (1) $\left({ }^{1} \mathrm{H} 700 \mathrm{MHz},{ }^{13} \mathrm{C} 175 \mathrm{MHz}, \mathrm{CD}_{3} \mathrm{OD}\right)$.

\begin{tabular}{|c|c|c|c|c|}
\hline Position & $\delta_{C}$, Type & & $\delta_{\mathrm{H}}$, Mult $(J$ in $\mathrm{Hz})$ & $\mathrm{HMBC}^{\mathrm{a}}$ \\
\hline 1 & $11.7\left(\mathrm{CH}_{3}\right)$ & & $1.25(\mathrm{t}, 7.5)$ & 2,3 \\
\hline 2 & $25.7\left(\mathrm{CH}_{2}\right)$ & $a, b$ & $2.71(\mathrm{~m})$ & 1,3 \\
\hline 3 & $167.5(\mathrm{C})$ & & - & \\
\hline 4 & $119.0(\mathrm{C})$ & & - & \\
\hline 5 & $182.0(\mathrm{C})$ & & - & \\
\hline 6 & $120.3(\mathrm{C})$ & & - & \\
\hline 7 & $167.7(\mathrm{C})$ & & - & \\
\hline 8 & $41.7(\mathrm{CH})$ & & 3.15 (quintet, 7.1 ) & 9,21 \\
\hline 9 & $75.6(\mathrm{CH})$ & & $4.02(t, 7.1)$ & $7,8,21,22$ \\
\hline 10 & $41.5(\mathrm{CH})$ & & 2.93 (quintet, 7.0 ) & $9,11,22$ \\
\hline 11 & $175.6(\mathrm{C})$ & & - & \\
\hline 12 & $109.2(\mathrm{C})$ & & - & \\
\hline 13 & $197.9(\mathrm{C})$ & & - & \\
\hline 14 & $41.5(\mathrm{CH})$ & & $2.53(\mathrm{dq}, 12.8,6.9)$ & $13,15,24$ \\
\hline 15 & $88.0(\mathrm{CH})$ & & $3.84(\mathrm{dd}, 12.8,3.0)$ & \\
\hline 16 & $36.6(\mathrm{CH})$ & & $1.78(\mathrm{~m})$ & \\
\hline 17 & $23.0\left(\mathrm{CH}_{2}\right)$ & $\begin{array}{l}a \\
b\end{array}$ & $\begin{array}{l}1.64(\mathrm{~m}) \\
1.29(\mathrm{~m})\end{array}$ & \\
\hline 18 & $12.1\left(\mathrm{CH}_{3}\right)$ & & $0.98(t, 7.5)$ & 16,17 \\
\hline 19 & $9.6\left(\mathrm{CH}_{3}\right)$ & & $1.93(\mathrm{~s})$ & $3,4,5$ \\
\hline 20 & $10.1\left(\mathrm{CH}_{3}\right)$ & & $1.91(\mathrm{~s})$ & $5,6,7$ \\
\hline 21 & $15.5\left(\mathrm{CH}_{3}\right)$ & & $1.28(\mathrm{~d}, 7.1)$ & $7,8,9$ \\
\hline 22 & $14.1\left(\mathrm{CH}_{3}\right)$ & & $1.26(\mathrm{~d}, 6.9)$ & $9,10,11$ \\
\hline 23 & $9.4\left(\mathrm{CH}_{3}\right)$ & & $1.63(\mathrm{~s})$ & $11,12,13$ \\
\hline 24 & $10.7\left(\mathrm{CH}_{3}\right)$ & & $1.06(\mathrm{~d}, 6.9)$ & $13,14,15$ \\
\hline 25 & $16.6\left(\mathrm{CH}_{3}\right)$ & & $1.11(\mathrm{~d}, 6.9)$ & $15,16,17$ \\
\hline
\end{tabular}

${ }^{\mathrm{a}} \mathrm{HMBC}$ correlations from proton stated to the indicated carbon.

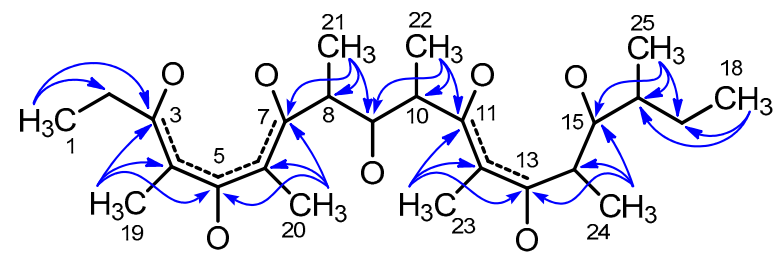

Figure 3. HMBC correlations (blue arrows) of methyl protons unequivocally defined the whole carbon skeleton of $\mathbf{1}$. The $\pi$ systems are depicted as dashed lines.

The chemical shifts of the carbon atoms allowed the identification of two groups of contiguous $s p^{2}$ carbon atoms, which are composed of five (C-3-C-7) and three (C-11-C-13) carbon atoms respectively. Among them, C-3, C-5, C-7, C-11, and C-13 were bonded to an oxygen atom, which is shown by their respective ${ }^{13} \mathrm{C}$ chemical shifts. Two oxygen-bound $s p^{3}$ carbon atoms (C-9 and C-15) were also present. The ${ }^{13} \mathrm{C}$ chemical shift also suggested that the C-3-C-7 system is part of a pyrone because they fit well with the values reported for the similar tetrasubstituted pyrone system present in auripyrones $\mathrm{A}$ and B [6]. Likewise, the C-11-C-13 system (together with C-14 and C-15) was part of a tetrasubstituted dihydropyrone, which was suggested by a comparison of the chemical shift of $\mathbf{1}$ with those of the corresponding atoms of maurenone $[18,19]$. Therefore, the sole hydroxyl group in the molecule was linked to C-9. This completed the planar structure of $\mathbf{1}$, which was further confirmed by the analysis of the fragment ions present in the tandem mass spectrum (Figure 4). 


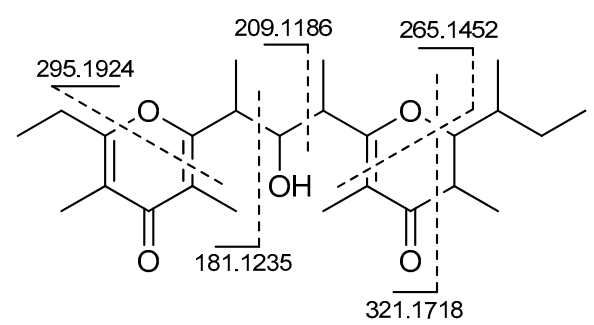

Figure 4. The main fragment peaks detected in the ESI tandem mass spectrum of smenopyrone (1).

Determination of the stereochemistry of smenopyrone (1) was based on the following evidence. The large coupling constant between $\mathrm{H}-14$ and $\mathrm{H}-15$ showed them to be trans-axial and demonstrated the trans orientation of the groups at C-14 and C-15 (in the following discussion, we will assume the 14S,15S absolute configuration for these carbon atoms, which will eventually be proven correct). Configuration at C-9, C-10, and C-16 was based on a comparison of ${ }^{13} \mathrm{C}$ NMR chemical shifts of smenopyrone (1) with those of the corresponding carbons of synthetic models, i.e., eight diastereomers of maurenone [19] (4-11, Figure 5). The chemical shift of C-25, which is very similar to that of compounds 4-7 but very far from that of compounds 8-11, clearly demonstrated the $S$ configuration at C-16. Configurations at C-9 and C-10 were based on an overall comparison with ${ }^{13} \mathrm{C}$ NMR chemical shifts of model compounds, which were expressed as the sum of the absolute values of chemical shift differences, $\Sigma|\Delta \delta|$ (Table S1 and Figure 6 and Figure S1). The best fit $(\Sigma|\Delta \delta|=3.1$ ) was shown by model compound 6 and, therefore, the configuration was assigned as 9S,10S. The configuration at C-8 was assigned based on the observation that, in the isomers of the model compound 2,4-diphenyl-3-pentanol (2) (Figure 5), the ${ }^{13} \mathrm{C}$ NMR chemical shifts of the methyl groups are remarkably different whether they are syn $\left(\delta_{C} \approx 15\right)$ or anti $\left(\delta_{C} \approx 19\right)$ to the OH group (Figure 5) [20]. This implied that C-21 and C-22 (both resonating at about $\delta 15$ ) are both syn to the OH group at C-9 and, therefore, confirmed the relative configuration between C-9 and C-10 and determined the $R$ configuration at C-8.

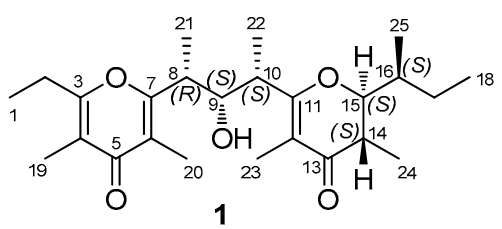

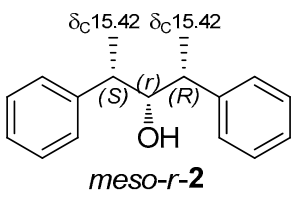

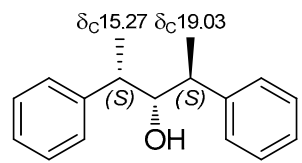
dl-2<smiles>CC[C@H](C)[C@@H]1OC([C@H](C)[C@@H](O)CC)=C(C)C(=O)[C@@H]1C</smiles><smiles>CC[C@H](O)[C@H](C)C1=C(C)C(=O)C(C)[C@H](C)O1</smiles>

10

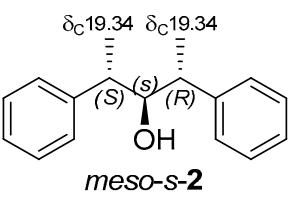<smiles>CCC1=CO[C@H]2CCC3CCC(N3)[C@@H]2C1=O</smiles>

3<smiles>CC[C@H](O)[C@@H](C)C1=C(C)C(=O)[C@H](C)C([C@@H](C)CC)([C@@H](C)CC)O1</smiles><smiles>CC[C@H](O)[C@@H](C)[C@H]1O[C@](C)(CC)C(C)=C(C)C1=O</smiles>

11

Figure 5. The three possible diastereomers of 2,4-diphenyl-3-pentanol (2), pinnamine (3), and the eight diastereomers of maurenone (4-11, the relative configuration of natural maurenone is as in 6). These compounds were used as model compounds to elucidate the stereochemistry of smenopyrone (1). ${ }^{13} \mathrm{C}$ NMR chemical shifts shown for 2 are adapted from Reference 20. 


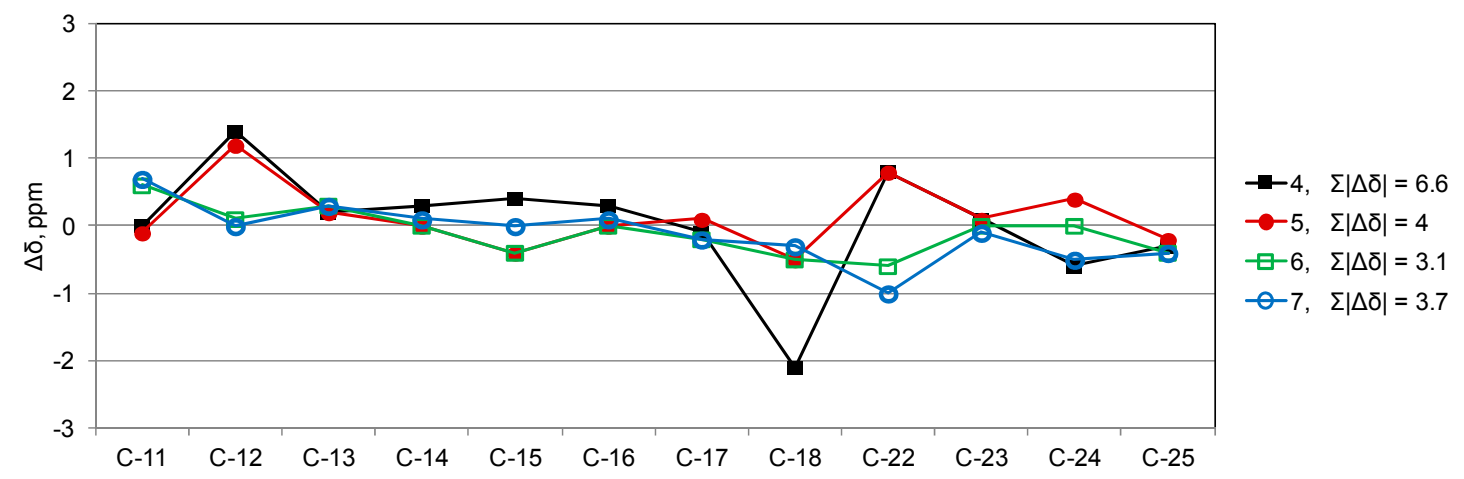

Figure 6. Difference in ${ }^{13} \mathrm{C}$ NMR chemical shift $(\Delta \delta)$ between corresponding atoms of smenopyrone (1) and the four stereoisomers of the model compound maurenone (4-7). The sum of absolute values of $\Delta \delta(\Sigma|\Delta \delta|)$ was used to evaluate the overall fit between smenopyrone and 4-7. Complete data can be found in Table S1 and Figure S1.

The absolute configuration of smenopyrone was based on its ECD spectrum. Smenopyrone (1) contains two chromophores including a $\gamma$-dihydropyrone and a $\gamma$-pyrone. A trans-disubstituted $\gamma$-dihydropyrone as in $\mathbf{1}$ exists predominantly in the half-chair conformation with trans-diequatorial substituents (this is supported by the $12.8 \mathrm{~Hz}$ coupling constant between $\mathrm{H}-14$ and $\mathrm{H}-15$ ). In a half-chair, the enone system is slightly skewed and becomes an inherently chiral chromophore, which is expected to dominate the ECD spectrum. In contrast, a $\gamma$-pyrone is a planar, non-chiral chromophore and is expected to give a minor contribution to the overall ECD spectrum. The ECD curve recorded for smenopyrone (1) (Figure S2) showed a profile very similar to the ECD spectrum of the $\gamma$-dihydropyrone alkaloid pinnamine (3) [21], but also showed an opposite sign. This suggests that the $\gamma$-dihydropyrone moiety of $\mathbf{1}$ has the opposite configuration compared to pinnamine (3), which, therefore, defines the $(8 R, 9 S, 10 S, 13 S, 14 S, 15 S)$ absolute configuration for smenopyrone (1).

\section{Discussion}

Smenopyrone (1) is the first pyrone polypropionate isolated from a marine sponge. It contains a bis- $\gamma$-pyrone structure similar to that of auripyrones $A$ and $B$, which were previously isolated from the Japanese sea hare Dolabella auricularia. These compounds are typical of some classes of marine mollusks but are also commonly found in terrestrial and marine fungi. It has been shown that polypropionates are biosynthesized through two entirely different pathways in mollusks and fungi even when the chemical structure of the synthesized compound is the same [22]. In mollusks, intact propionate units are introduced in the growing polyketide chain by incorporating methylmalonyl-CoA. In fungi, methyl branches are derived from methylation by $S$-adenosyl methionine (SAM).

Recently, a series of closely related $\gamma$-pyrone polypropionates known as nocapyrones A-C and H-Q was shown to be produced by the bacterial symbiont Nocardiopsis alba CR167 isolated from the mollusk Conus rolani [23]. An iterative type-I polyketide synthase gene cluster has been identified as responsible for the biosynthesis of these compounds whose dipropionate backbone derives from condensation of two methylmalonyl CoA units. Additionally, it can be predicted that smenopyrone is assembled by an iterative type-I polyketide synthase through the condensation of one acetate unit and eight methylmalonyl-CoA units. The definite bacterial origin of nocapyrones suggests that other polypropionates from mollusks can be produced by bacteria and the same may hold true for sponge-derived smenopyrone. However, if nocapyrones are only occasionally found in C. rolani because $N$. alba is a casual symbiont of this mollusk, it is important to mention that the presence of smenopyrone (1) is by no means occasional in S. aurea because the compound has been consistently found in all specimens of Caribbean S. aurea we studied and is also present in the closely related 
species S. conulosa. Therefore, smenopyrone (1) is likely to be produced by obligate rather than casual sponge-symbionts.

These ideas also suggest an intriguing speculation about the role of smenopyrone in sponges. Sponges are sessile filter animals that harbor communities of microorganisms, which are either digested as a nutrient source or take part in a complex symbiotic relationship with the sponge. These host-associated bacteria make up $30 \%$ to $40 \%$ of sponge mass [24,25] and are often the real producer of the secondary metabolites isolated from the sponge extract. For example, in the case of the group of manzamine alkaloids, which is originally isolated from the sponge Acanthostrongylophora ingens, is subsequently shown to be produced by the associated actinomycete Micromonspora [26,27]. The idea of a possible inter-kingdom communication [28] between bacteria and sponges mediated by small molecules (e.g., lactones, which are regularly produced by many bacteria) is intriguing. It has been recently explored and demonstrated that, in the sponge Suberites domuncula [29,30], the $\mathrm{N}$-3-oxodecanoyl-L-homoserine lactone can affect the expression of immune and apoptotic genes of the host and possibly enable the sponge to monitor bacterial community. Moreover, molecules affecting the quorum-sensing system (the system of bacteria use to communicate) were found in sponge extracts [31], which suggests the possibility of complex communications and interactions between the two kingdoms.

Endogenous pyrone-containing polyketides have been recently identified as the signaling molecules of a previously orphan signal system of proteobacteria [32]. It is, therefore, exceedingly easy to speculate that smenopyrone may similarly function as a signaling molecule and mediate the communication between obligate symbiotic bacteria of $S$. aurea and the host sponge. While this is merely a fascinating speculation at present, it is worth pursuing this hypothesis in order to determine if, in fact, smenopyrone or related pyrone polypropionates act as inter-kingdom signaling molecules for bacterial symbionts of sponges or mollusks.

\section{Materials and Methods}

\subsection{General Experimental Procedure}

ECD spectra were recorded using a Jasco-715 spectropolarimeter (Easton, MD, USA). NMR spectra were determined on Varian Unity Inova spectrometers at $700 \mathrm{MHz}$ and $500 \mathrm{MHz}$. Chemical shifts were referenced to the residual solvent signal $\left(\mathrm{CD}_{3} \mathrm{OD}: \delta_{\mathrm{H}} 3.31, \delta_{\mathrm{C}} 49.0 ; \mathrm{CDCl}_{3}: \delta_{\mathrm{H}} 7.26, \delta_{\mathrm{C}} 77.0\right)$. For an accurate measurement of the coupling constants, the one-dimensional ${ }^{1} \mathrm{H}$ NMR spectra were transformed at $128 \mathrm{~K}$ points (digital resolution $<0.1 \mathrm{~Hz}$ ). The HSQC spectra were optimized for ${ }^{1} J_{\mathrm{CH}}=142 \mathrm{~Hz}$ and the ${ }^{13} \mathrm{C}$ HMBC experiments for ${ }^{2,3} J_{\mathrm{CH}}=8.3 \mathrm{~Hz}$. High-resolution ESI-MS and MS/MS experiments were performed on a Thermo LTQ Orbitrap XL mass spectrometer (Thermo Fisher Scientific Spa, Rodano, Italy) coupled to a Thermo U3000 HPLC system (Agilent Technology, Cernusco sul Naviglio, Italy). High performance liquid chromatography (HPLC) separations were achieved on an Agilent 1260 Infinity Quaternary LC apparatus (Agilent Technology, Cernusco sul Naviglio, Italy) equipped with a Diode-Array Detector (DAD).

\subsection{Collections, Extraction, and Isolation}

A specimen of Smenospongia aurea (712 g wet weight) was collected on the 9 July 2013 at depths of $15 \mathrm{~m}$ by scuba diving along the coast of Great Inagua (Bahamas Islands, $21^{\circ} 03^{\prime} 24.55^{\prime \prime}$ $\mathrm{N}-73^{\circ} 25^{\prime} 27.76^{\prime \prime} \mathrm{W}$ ). The collected sample was a relatively small portion of a much larger sponge and was excised with a sharp scalpel to minimally affect the remaining sponge tissue and allow recovery and regrowth. After collection, the sample was unambiguously identified onboard using a web-based photographic and taxonomic key, known as The Sponge Guide (www.spongeguide.org), with subsequent confirmation by sponge taxonomist Sven Zea. The sample was frozen immediately after collection and stored at $-20^{\circ} \mathrm{C}$ until extraction. A voucher specimen of the organism is stored 
at Dipartimento di Farmacia, "TheBlueChemistryLab" laboratory, Università degli Studi di Napoli "Federico II" with the reference number 06/07/13.

To perform the present study, the sample was allowed to reach room temperature, then cut in small pieces, homogenized, and extracted following our standard procedure [33]. The total organic extract $(16.31 \mathrm{~g})$ was chromatographed on a column packed with RP-18 silica gel. The fraction was eluted with $\mathrm{MeOH} / \mathrm{H}_{2} \mathrm{O}(9: 1,363.7 \mathrm{mg})$ and was partitioned in a two-phase system composed of $\mathrm{H}_{2} \mathrm{O}$ $(160 \mathrm{~mL}), \mathrm{MeOH}(260 \mathrm{~mL}), \mathrm{CHCl}_{3}(140 \mathrm{~mL})$, and $\mathrm{AcOH}(5 \mathrm{~mL})$. The organic layer, which contained smenothiazoles [34], smenamides [35], and smenopyrone (1), was subjected to reversed-phase HPLC separation (column $250 \times 10 \mathrm{~mm}, 10 \mu \mathrm{m}$, Luna (Phenomenex) C18, eluent $\mathrm{A}: \mathrm{H}_{2} \mathrm{O}$, eluent $\mathrm{B}: \mathrm{MeOH}$, gradient: $55 \rightarrow 100 \% \mathrm{~B}$, over $60 \mathrm{~min}$, flow rate $\left.5 \mathrm{~mL} \mathrm{~min}^{-1}\right)$, which affords a fraction $\left(t_{R}=29 \mathrm{~min}\right.$ ) containing compound 1 . The former fraction was subjected to new separations on reversed-phase HPLC (column $250 \times 4.6 \mathrm{~mm}, 5 \mu \mathrm{m}$, Luna (Phenomenex) C18, eluent $\mathrm{A}: \mathrm{H}_{2} \mathrm{O}$, eluent $\mathrm{B}: \mathrm{ACN}$, gradient: $50 \rightarrow 100 \% \mathrm{~B}$, over $35 \mathrm{~min}$, flow rate $\left.1 \mathrm{~mL} \mathrm{~min}^{-1}\right)$, which gave $12 \mu \mathrm{g}$ of a pure compound $\mathbf{1}\left(\mathrm{t}_{\mathrm{R}}=16 \mathrm{~min}\right)$.

Smenopyrone (1): Colorless glass, UV (MeOH): $\lambda_{\max }(\varepsilon) 260$ (21,600), ECD (MeOH): $\lambda_{\max }(\Delta \varepsilon) 306$ (+1.2), 277 (-5.5), HR-ESI-MS (High Resolution-ElectroSpray Ionization-Mass Spectrometry) (positive ion mode, $\mathrm{MeOH}) \mathrm{m} / z$ 419.2780, $[\mathrm{M}+\mathrm{H}]^{+}\left(\mathrm{C}_{25} \mathrm{H}_{39} \mathrm{O}_{5}{ }^{+}\right.$gives 419.2792, $\left.\Delta-2.8 \mathrm{ppm}\right),{ }^{1} \mathrm{H} \mathrm{NMR}\left(\mathrm{CDCl}_{3}\right)$ : $3.99(\mathrm{dd}, J=8.0$ and $4.6 \mathrm{~Hz}, \mathrm{H}-9), 3.84(\mathrm{~m}, \mathrm{H}-15), 3.07(\mathrm{dq}, J=8,0$ and $7.0 \mathrm{~Hz}, \mathrm{H}-8), 2.92(\mathrm{dq}, J=4.6$ and $7.0 \mathrm{~Hz}, \mathrm{H}-10), 2.71\left(\mathrm{q}, J=7.6 \mathrm{~Hz}, \mathrm{H}_{2}-2\right), 2.51(\mathrm{dq}, J=12.4$ and $3.2 \mathrm{~Hz}, \mathrm{H}-14), 1.94\left(\mathrm{~s}, \mathrm{H}_{3}-20\right)$, 1.94 (s, $\left.\mathrm{H}_{3}-19\right), 1.76$ (m, H-16), 1.67 (s, $\left.\mathrm{H}_{3}-23\right), 1.62$ (m, H-17a), 1.26 (m, H-17b), 1.24 (d, J = $7.0 \mathrm{~Hz}$, $\left.\mathrm{H}_{3}-22\right), 1.24\left(\mathrm{~d}, J=7.0 \mathrm{~Hz}, \mathrm{H}_{3}-21\right), 1.22\left(\mathrm{t}, J=7.6 \mathrm{~Hz}, \mathrm{H}_{3}-1\right), 1.09\left(\mathrm{~d}, J=6.9 \mathrm{~Hz}, \mathrm{H}_{3}-24\right), 1.05(\mathrm{~d}, J=6.9 \mathrm{~Hz}$, $\left.\mathrm{H}_{3}-25\right), 0.94\left(\mathrm{t}, J=7.4, \mathrm{H}_{3}-18\right) ;{ }^{13} \mathrm{C}$ NMR $\left(\mathrm{CDCl}_{3}\right)$ : 195.4 (C, C-13), 179.5 (C, C-5), $172.4(\mathrm{C}, \mathrm{C}-11)$, 164.0 (C, C-3), 164.7 (C, C-7), 118.2 (C, C-4), 119.4 (C, C-6), 108.5 (C, C-12), 87.4 (CH, C-15), 75.1 (CH, C-9), $40.6(\mathrm{CH}, \mathrm{C}-14), 38.6(\mathrm{CH}, \mathrm{C}-10), 38.3(\mathrm{CH}, \mathrm{C}-8), 35.1(\mathrm{CH}, \mathrm{C}-16), 26.2\left(\mathrm{CH}_{2}, \mathrm{C}-2\right), 22.1\left(\mathrm{CH}_{2}, \mathrm{C}-17\right)$, $16.5\left(\mathrm{CH}_{3}, \mathrm{C}-25\right), 15.3\left(\mathrm{CH}_{3}, \mathrm{C}-21\right), 13.9\left(\mathrm{CH}_{3}, \mathrm{C}-22\right), 12.2\left(\mathrm{CH}_{3}, \mathrm{C}-18\right), 11.6\left(\mathrm{CH}_{3}, \mathrm{C}-1\right), 10.6\left(\mathrm{CH}_{3}, \mathrm{C}-24\right)$, $9.8\left(\mathrm{CH}_{3}, \mathrm{C}-20\right)$, $9.4\left(\mathrm{CH}_{3}, \mathrm{C}-19\right), 9.3\left(\mathrm{CH}_{3}, \mathrm{C}-23\right),{ }^{1} \mathrm{H}$, and ${ }^{13} \mathrm{C}$ NMR $\left(\mathrm{CD}_{3} \mathrm{OD}\right)$ : Table 1.

Supplementary Materials: The following are available online at http:/ / www.mdpi.com/1660-3397/16/8/285/s1, Table S1: ${ }^{13} \mathrm{C}$ NMR chemical shift of smenopyrone 1 compared with those of the eight diastereomers of maurenone 4-11, Figure S1: Difference in ${ }^{13} \mathrm{C}$ NMR chemical shift between corresponding atoms of $\mathbf{1}$ and 4-11, Figure S2: UV and ECD spectra of 1, Figure S3: High-resolution ESI mass spectrum of 1, Figure S4: High-resolution ESI MS/MS spectrum (parent ion at $\mathrm{m} / \mathrm{z}$ 419.28) and fragmentation of 1, Figures S5-S10: ${ }^{1} \mathrm{H}-\mathrm{NMR}, \mathrm{COSY}, \mathrm{NOESY,} \mathrm{HSQC,}$ and $\mathrm{HMBC}$ spectra of $\mathbf{1}\left(700 \mathrm{MHz}, \mathrm{CD}_{3} \mathrm{OD}\right)$.

Author Contributions: Conceptualization, A.M. and V.C. Data curation, G.E., R.T., and G.D.S. Funding acquisition, A.M. and V.C. Investigation, G.E., R.T. and G.D.S. Supervision, J.R.P. and V.C. Writing-review \& editing, A.M. and V.C.

Funding: We acknowledge the financial support of the European Union 7th Framework Programme (BlueGenics, FP7-KBBE-2012-6) under grant agreement no. 311848 and by Università degli Studi di Napoli Federico II under the STAR project named SeaLEADS.

Acknowledgments: Sponge collection was made possible by UNOLS funding through a grant from the US-NSF Biological Oceanography Programme (OCE 1029515) and the crew of the R/V Walton Smith (University of Miami). Warm thanks are due to Sven Zea (Universidad Nacional de Colombia) for confirming the identification aboard the ship.

Conflicts of Interest: The authors declare no conflict of interest. The funders had no role in the design of the study, in the collection, analyses, or interpretation of data, in the writing of the manuscript, or in the decision to publish the results.

\section{References}

1. Wilk, W.; Waldmann, H.; Kaiser, M. $\gamma$-Pyrone natural products-A privileged compound class provided by nature. Bioorg. Med. Chem. 2009, 17, 2304-2309. [CrossRef] [PubMed]

2. Pawlik, J.R. Marine Invertebrate Chemical Defenses. Chem. Rev. 1993, 93, 1911-1922. [CrossRef]

3. Davies-Coleman, M.T.; Garson, M.J. Marine polypropionates. Nat. Prod. Rep. 1998, 15, 477-493. [CrossRef] [PubMed] 
4. Carbone, M.; Ciavatta, M.L.; Wang, J.R.; Cirillo, I.; Mathieu, V.; Kiss, R.; Mollo, E.; Guo, Y.W.; Gavagnin, M. Extending the Record of Bis- $\gamma$-pyrone Polypropionates from Marine Pulmonate Mollusks. J. Nat. Prod. 2013, 76, 2065-2073. [CrossRef] [PubMed]

5. Zhou, Z.F.; Li, X.L.; Yao, L.G.; Li, J.; Gavagnin, M.; Guo, Y.W. Marine bis- $\gamma$-pyrone polypropionates of onchidione family and their effects on the XBP1 gene expression. Bioorg. Med. Chem. Lett. 2018, 28, 1093-1096. [CrossRef] [PubMed]

6. Suenaga, K.; Kigoshi, H.; Yamada, K. Auripyrones A and B, cytotoxic polypropionates from the sea hare Dolabella auricularia: Isolation and structures. Tetrahedron Lett. 1996, 37, 5151-5154. [CrossRef]

7. Bai, R.; Petit, G.R.; Hamel, E. Dolastatin 10, a powerful cytostatic peptide derived from a marine animal: Inhibition of tubulin polymerization mediated through the vinca alkaloid binding domain. Biochem. Pharmacol. 1990, 39, 1941-1949. [CrossRef]

8. Costantino, V.; Fattorusso, E.; Imperatore, C.; Mangoni, A. Ectyoceramide, the First Natural Hexofuranosylceramide from the Marine Sponge Ectyoplasia ferox. Eur. J. Org. Chem. 2003, 8, 1433-1437. [CrossRef]

9. Costantino, V.; D’Esposito, M.; Fattorusso, E.; Mangoni, A.; Basilico, N.; Parapini, S.; Taramelli, D. Damicoside from Axinella damicornis: The influence of a glycosylated galactose 4-OH group on the immunostimulatory activity of $\alpha$-galactoglycosphingolipids. J. Med. Chem. 2005, 48, 7411-7417. [CrossRef] [PubMed]

10. Costantino, V.; Fattorusso, E.; Imperatore, C.; Mangoni, A. Glycolipids from sponges. Part 17. Clathrosides and Isoclathrosides, Unique Glycolipids from the Caribbean Sponge Agelas clathrodes. J. Nat. Prod. 2006, 69, 73-78. [CrossRef] [PubMed]

11. Lamoral-Theys, D.; Fattorusso, E.; Mangoni, A.; Perinu, C.; Kiss, R.; Costantino, V. Evaluation of the antiproliferative activity of diterpene isonitriles from the sponge Pseudoaxinella flava in apoptosis-sensitive and apoptosis-resistant cancer cell lines. J. Nat. Prod. 2011, 74, 2299-2303. [CrossRef] [PubMed]

12. Esposito, G.; Della Sala, G.; Teta, R.; Caso, A.; Bourguet-Kondracki, M.L.; Pawlik, J.R.; Mangoni, A.; Costantino, V. Chlorinated Thiazole-Containing Polyketide-Peptides from the Caribbean Sponge Smenospongia conulosa: Structure Elucidation on Microgram Scale. Eur. J. Org. Chem. 2016, 16, 2871-2875. [CrossRef]

13. Caso, A.; Mangoni, A.; Piccialli, G.; Costantino, V.; Piccialli, V. Studies toward the Synthesis of Smenamide A, an Antiproliferative Metabolite from Smenospongia aurea: Total Synthesis of ent-Smenamide A and 16-epi-Smenamide A. ACS Omega 2017, 2, 1477-1488. [CrossRef] [PubMed]

14. Caso, A.; Laurenzana, I.; Lamorte, D.; Trino, S.; Esposito, G.; Piccialli, V.; Costantino, V. Smenamide A Analogues. Synthesis and Biological Activity on Multiple Myeloma Cells. Mar. Drugs 2018, 16, 206. [CrossRef] [PubMed]

15. Pawlik, J.R. Thechemical ecology of sponges on Caribbeanreefs: Natural products shape natural systems. Bioscience 2011, 61, 888-898. [CrossRef]

16. Costantino, V.; Fattorusso, E.; Mangoni, A.; Perinu, C.; Teta, R.; Panza, E.; Ianaro, A. Tedarenes A and B: Structural and stereochemical analysis of two new strained cyclic diarylheptanoids from the marine sponge Tedania ignis. J. Org. Chem. 2012, 77, 6377-6383. [CrossRef] [PubMed]

17. Mangoni, A. Strategies for Structural Assignment of Marine Natural Products Through Advanced NMR-based Techniques. In Handbook of Marine Natural Products; Springer: Dordrecht, The Netherlands, 2012; pp. 518-546.

18. Manker, D.C.; Faulkner, D.J.; Xe, C.F.; Clardy, J. Metabolites of Siphonaria maura from Costa Rica. J. Org. Chem. 1986, 51, 814-816. [CrossRef]

19. Crossman, J.S.; Perkins, M.V. Total Synthesis and Structural Elucidation of (-)-Maurenone. J. Org. Chem. 2006, 71, 117-124. [CrossRef] [PubMed]

20. Schwink, L.; Knochel, P. Enantioselective Preparation of $\mathrm{C}_{2}$-Symmetrical Ferrocenyl Ligands for Asymmetric Catalysis. Chem. Eur. J. 1998, 4, 950-968. [CrossRef]

21. Takada, N.; Iwatsuki, M.; Suenaga, K.; Uemura, D. Pinnamine, an alkaloidal marine toxin, isolated from Pinna muricata. Tetrahedron Lett. 2000, 41, 6425-6428. [CrossRef]

22. Cutignano, A.; Villani, G.; Fontana, A. One metabolite, two pathways: Convergence of polypropionate biosynthesis in fungi and marine molluscs. Org. Lett. 2012, 14, 992-995. [CrossRef] [PubMed] 
23. Lin, Z.; Torres, J.P.; Ammon, M.A.; Marett, L.; Teichert, R.W.; Reilly, C.A.; Kwan, J.C.; Hughen, R.W.; Flores, M.; Tianero, M.D.; et al. A bacterial source for mollusk pyrone polyketides. Chem. Biol. 2013, 20, 73-81. [CrossRef] [PubMed]

24. Hentschel, U.; Usher, K.M.; Taylor, M.W. Marine sponges as microbial fermenters. FEMS Microbiol. Ecol. 2006, 55, 167-177. [CrossRef] [PubMed]

25. Laroche, M.; Imperatore, C.; Grozdanov, L.; Costantino, V.; Mangoni, A.; Hentschel, U.; Fattorusso, E. Cellular localisation of secondary metabolites isolated from the Caribbean sponge Plakortis simplex. Mar. Biol. 2007, 151, 1365-1373. [CrossRef]

26. Waters, A.L.; Peraud, O.; Kasanah, N.; Sims, J.W.; Kothalawala, N.; Anderson, M.A.; Abbas, S.H.; Rao, K.V.; Jupally, V.R.; Kelly, M.; et al. An analysis of the sponge Acanthostrongylophora igens' microbiome yields an actinomycete that produces the natural product manzamine A. Front. Mar. Sci. 2014, 1, 54. [CrossRef] [PubMed]

27. Esposito, G.; Bourguet-Kondracki, M.L.; Mai, L.H.; Longeon, A.; Teta, R.; Meijer, L.; Van Soest, R.; Mangoni, A.; Costantino, V. Chloromethylhalicyclamine B, a Marine-Derived Protein Kinase CK1 $/ \varepsilon$ Inhibitor. J. Nat. Prod. 2016, 79, 2953-2960. [CrossRef] [PubMed]

28. González, J.F.; Venturi, V. A novel widespread interkingdom signaling circuit. Trends Plant Sci. 2013, 18, 167-174. [CrossRef] [PubMed]

29. Gardères, J.; Taupin, L.; Saidin, J.B.; Dufour, A.; Le Pennec, G. N-acyl homoserine lactone production by bacteria within the sponge Suberites domuncula (Olivi, 1972) (Porifera, Demospongiae). Mar. Biol. 2012, 159, 1685-1692. [CrossRef]

30. Gardères, J.; Henry, J.; Bernay, B.; Ritter, A.; Zatylny-Gaudin, C.; Wiens, M.; Müller, W.E.; Le Pennec, G. Cellular Effects of Bacterial N-3-Oxo-Dodecanoyl-L-Homoserine Lactone on the Sponge Suberites domuncula (Olivi, 1792): Insights into an Intimate Inter-Kingdom Dialogue. PLoS ONE 2014, 9, e97662. [CrossRef] [PubMed]

31. Costantino, V.; Della Sala, G.; Saurav, K.; Teta, R.; Bar-Shalom, R.; Mangoni, A.; Steindler, L. Plakofuranolactone as a Quorum Quenching Agent from the Indonesian Sponge Plakortis cf. lita. Mar. Drugs 2017, 15, 59. [CrossRef] [PubMed]

32. Brachmann, A.O.; Brameyer, S.; Kresovic, D.; Hitkova, I.; Kopp, Y.; Manske, C.; Schubert, K.; Bode, H.B.; Heermann, R. Pyrones as bacterial signaling molecules. Nat. Chem. Biol. 2013, 9, 573-578. [CrossRef] [PubMed]

33. Teta, R.; Della Sala, G.; Glukhov, E.; Gerwick, L.; Gerwick, W.H.; Mangoni, A.; Costantino, V. Combined LC-MS/MS and Molecular Networking Approach Reveals New Cyanotoxins from the 2014 Cyanobacterial Bloom in Green Lake, Seattle. Environ. Sci. Technol. 2015, 49, 14301-14310. [CrossRef] [PubMed]

34. Esposito, G.; Teta, R.; Miceli, R.; Ceccarelli, L.S.; Della Sala, G.; Camerlingo, R.; Irollo, E.; Mangoni, A.; Pirozzi, G.; Costantino, V. Isolation and Assessment of the in Vitro Anti-Tumor Activity of Smenothiazole A and B, Chlorinated Thiazole-Containing Peptide/Polyketides from the Caribbean Sponge, Smenospongia aurea. Mar. Drugs 2015, 13, 444-459. [CrossRef] [PubMed]

35. Teta, R.; Irollo, E.; Della Sala, G.; Pirozzi, G.; Mangoni, A.; Costantino, V. Smenamides A and B, Chlorinated Peptide/Polyketide Hybrids Containing a Dolapyrrolidinone Unit from the Caribbean Sponge Smenospongia aurea. Evaluation of Their Role as Leads in Antitumor Drug Research. Mar. Drugs 2013, 11, 4451-4463. [CrossRef] [PubMed]

(C) 2018 by the authors. Licensee MDPI, Basel, Switzerland. This article is an open access article distributed under the terms and conditions of the Creative Commons Attribution (CC BY) license (http:/ / creativecommons.org/licenses/by/4.0/). 